\title{
Using Fine Silica Sand and Granite Powder Waste to Control Free Swelling Behavior of High Expansive Soil
}

\author{
Manal O. Suliman ${ }^{1} \&$ Abdulrazzaq Jawish Alkherret ${ }^{2}$ \\ ${ }^{1,2}$ Department of Civil Engineering, Jerash University, Jerash, Jordan \\ Correspondence: Manal O. Suliman, Department of Civil Engineering, Jerash University, Jerash, Jordan.
}

Received: November 28, 2020

Accepted: December 17, 2020

Online Published: December 28, 2020

doi:10.5539/mas.v15n1p53

URL: https://doi.org/10.5539/mas.v15n1p53

\begin{abstract}
Many researchers have been interested in studying the effect of adding local natural materials or construction waste on the properties of poor subgrade soil. However, changes in size and strength of expansive soils can cause extensive damage to the geotechnical infrastructure. This damage is often repeatable and latent in the long term, and is a critical issue in highway subgrade engineering. This paper examines the effect of adding both Fine Silica Sand (FSS) and Granite Cutting Powder Waste (GPW) materials on the welling characteristics of expansive soils. Atterberg limits, free swell index, and rate of swell of the mixtures were used as a key to assess properties of a group of expansive soil samples after adding different percentages of the mentioned materials. The rates of additions were $10 \%, 20 \%, 30 \%, 40 \%, 50 \%, 60$ and $70 \%$ of the weight of the soil samples. The test results showed that FSS and GPW significantly affect the expansive soil properties. However, adding 70\% of both FSS and GPW reduced the swelling index from $58.3 \%$ to $6.6 \%$ and from $58.3 \%$ to $11 \%$ after 7 days of curing, respectively. This study suggests that the Fine Silica Sand and Granite Powder Waste can be used as stabilizers for expansive highly plastic soils.
\end{abstract}

Keywords: high expansive soils, bentonite, silica sand, granite waste, swell, stabilization

\section{Introduction}

Expansive soils can be characterized by its potential for volume changes as well as can be characterized by its high strength when dry, very low strength when wet, wide and deep shrinkage cracks in the dry season, and high plasticity.

Expansive soils always cause problems because when they are used as foundation material for engineering structures such as subgrade for pavement structures, the latter are liable to suffer some distress and damage due to the excessive volume changes of the soil profiles. These changes occur as a result of an increase or a decrease in moisture content.

Expansive soils engineering properties need to be improved to make these soils suitable for construction purposes. Geotechnical properties of expansive soils are improved by different techniques. The problematic soil can be removed and replaced by a better-quality material or can be treated using mechanical or chemical stabilization. The most effective and economical methods to prevent volume changes of an expansive soils is through the use of additives materials.

The need for economic soil stabilizers materials and economic waste disposal cost has led to intense global research towards economic utilization of locally available materials and industry wastes for engineering purposes.

Recent trend in research works in the field of construction materials focused more on the use of potentially materials that are cheap and locally available such as industry wastes as additives materials for improvement of the soils properties such as Monica et al., Talal Masoud et al., Gupta Chayanet al., Sabat, Sabat and Nanda, Ravi Shanker Mishra, M. K. Gupta, Palaniappan and Stalin, Ene and Okagbue. These research works carried out to satisfy the safe and environmental disposal of industry waste, and the need for better and cost effective construction materials.

Considering the important of utilization of locally available materials as an alternative soil stabilization material, the purpose of the experimental work in this study is to investigate the effects of addition of locally granite cutting powder waste and locally fine silica sand materials on Atterberg limits, and free swell characteristics of 
expansive soils.

\section{Materials and Test Program}

This experimental study aims to investigate the effects of the addition of fine silica sand and granite cutting powder waste on swell characteristics of expansive soils and, to investigate the rate of swell of an expansive soil stabilized with fine silica sand and granite cutting powder waste.

\section{A. Expansive soil (Bentonite)}

In this study commercial bentonite clay was used to prepare a potentially expansive soil. Bentonite can be considered as a good grade of high swelling soil. The commercial bentonite used in this study without any treatment because it comes in the form of fine powder.

\section{B. Silica Sand}

Fine silica sand is locally available in Jordan and financially cheap. Fine silica sand was passed through No. 40 sieve before usage.

\section{Granite Cutting Powder Waste}

Locally available granite cutting powder waste was used. The important characteristic of granite cutting powder waste as an additive material is the percentage passing through No. 40 sieve. Since all particles of granite cutting powder waste pass through No. 40 sieve, all of granite cutting powder waste particles and bentonite can be used in Atterberg limit and free swelling tests without further sieving.

\section{Index Properties of Expansive Soil-Sand and Expansive Soil- Granite Powder Waste Mixtures}

To mix the sand and granite powder waste with expansive soils, both materials were first initially dried. A number of samples were prepared by mixing the expansive soils with $10 \%, 25 \%, 50 \%, 60 \%$, and $70 \%$, of fine silica sand and granite cutting powder waste. The prepared samples were then tested to determine the Atterberg limits and the swell properties. The measured index properties are liquid limit (LL), plastic limit (PL), and plasticity index (PI). To study the swelling property of the soils samples, the simplest free swell index test was conducted. Free swell index of expansive soil indicates the swell potential of a soil.

\section{Test Results and Discussions}

\section{A. Effect of Silica Sand and Granite Powder Waste on Expansive Soils Index Properties}

Index properties include consistency limits (LL, PL, and PI = LL-PL) of the all proposed soils samples are summarized in Table 1.The relationship between plasticity index and swell behavior of soil has been identified by several researchers; in this study the relationship suggested by O'neill and Poormaayed [10] is used.

Figure 1 to Figure 6 shows the relationship between Atterberg limits and percentage of fine silica sand and granite powder waste in graphical form.

Table 1. Relationships between plasticity index (PI) and swell potential (O'neill and Poormaayed) [10]

\begin{tabular}{ll}
\hline Swelling Potential & Plasticity Index \\
Low & $<25$ \\
Medium & $\mathbf{2 5 - 3 5}$ \\
High & $>35$ \\
\hline
\end{tabular}


Table 2. Proposed Expansive Soils Sample Properties and Classification Based on Plasticity Index Properties

\begin{tabular}{|c|c|c|c|c|c|c|c|c|}
\hline \multirow[t]{2}{*}{$\begin{array}{l}\text { Percentage } \\
\text { of Addition }\end{array}$} & \multicolumn{2}{|c|}{$\begin{array}{l}\text { Liquid Limit } \\
\text { (\%) }\end{array}$} & \multicolumn{2}{|c|}{$\begin{array}{c}\text { Plastic Limit } \\
\text { (\%) }\end{array}$} & \multicolumn{2}{|c|}{$\begin{array}{c}\text { Plasticity Index } \\
\text { PI }\end{array}$} & \multicolumn{2}{|c|}{$\begin{array}{c}\text { O'neill and } \\
\text { Poormaayed }[10] \\
\text { classification }\end{array}$} \\
\hline & $\begin{array}{l}\text { Fine } \\
\text { Silica } \\
\text { Sand } \\
\text { (FSS) }\end{array}$ & $\begin{array}{l}\text { GranitePo } \\
\text { wderWast } \\
\text { e (GPW) }\end{array}$ & $\begin{array}{l}\text { Fine } \\
\text { Silica } \\
\text { Sand } \\
\text { (FSS) }\end{array}$ & $\begin{array}{l}\text { Granite } \\
\text { Powder } \\
\text { Waste } \\
\text { (GPW) }\end{array}$ & $\begin{array}{l}\text { Fine } \\
\text { Silica } \\
\text { Sand } \\
\text { (FSS) }\end{array}$ & $\begin{array}{c}\text { Granite } \\
\text { Powder } \\
\text { Waste } \\
\text { (GPW) }\end{array}$ & $\begin{array}{l}\text { Fine } \\
\text { Silica } \\
\text { Sand } \\
\text { (FSS) }\end{array}$ & $\begin{array}{c}\text { Granite } \\
\text { Powder } \\
\text { Waste } \\
(G P W)\end{array}$ \\
\hline 0 & \multicolumn{2}{|c|}{342.5} & \multicolumn{2}{|c|}{74.67} & \multicolumn{2}{|c|}{267.83} & \multicolumn{2}{|r|}{ High } \\
\hline 10 & 315.8 & 332 & 66.43 & 67.03 & 249.37 & 264.97 & & High \\
\hline 20 & 306.25 & 320 & 65.39 & 66.03 & 240.86 & 253.97 & & High \\
\hline 30 & 287.5 & 303 & 57.93 & 59.66 & 229.57 & 243.34 & & High \\
\hline 40 & 245.4 & 271 & 52 & 54.4 & 193.4 & 216.6 & & High \\
\hline 50 & 215 & 252 & 49.23 & 51.37 & 165.77 & 201.63 & & High \\
\hline 60 & 190 & 216.6 & 47.57 & 48.1 & 142.43 & 168.5 & & High \\
\hline 70 & 170 & 185.2 & 44.88 & 46.7 & 124.12 & 138.5 & & High \\
\hline
\end{tabular}

Table 3. Percent Changes in Liquid Limit, Plastic Limit, and Plasticity Index Values

\begin{tabular}{|c|c|c|c|c|c|c|}
\hline \multirow[t]{2}{*}{$\begin{array}{l}\text { Percentage of } \\
\text { Addition }\end{array}$} & \multicolumn{2}{|c|}{$\begin{array}{c}\text { \% Change in Liquid } \\
\text { Limit }\end{array}$} & \multicolumn{2}{|c|}{$\begin{array}{c}\text { \% Change in Plastic } \\
\text { Limit }\end{array}$} & \multicolumn{2}{|c|}{$\begin{array}{c}\text { \% Change in Plasticity } \\
\text { Index (PI) }\end{array}$} \\
\hline & $\begin{array}{l}\text { Fine Silica } \\
\text { Sand (FSS) }\end{array}$ & $\begin{array}{c}\text { Granite } \\
\text { Powder } \\
\text { Waste } \\
(\mathrm{GPW})\end{array}$ & $\begin{array}{l}\text { Fine Silica } \\
\text { Sand (FSS) }\end{array}$ & $\begin{array}{c}\text { Granite } \\
\text { Powder } \\
\text { Waste } \\
\text { (GPW) }\end{array}$ & $\begin{array}{l}\text { Fine Silica } \\
\text { Sand (FSS) }\end{array}$ & $\begin{array}{c}\text { Granite Powder } \\
\text { Waste (GPW) }\end{array}$ \\
\hline $\mathbf{0}$ & \multicolumn{2}{|c|}{0.00} & \multicolumn{2}{|c|}{0.00} & \multicolumn{2}{|c|}{0.00} \\
\hline 10 & -7.7 & -3 & -11 & -10.2 & -6.9 & $1.1-$ \\
\hline 20 & -10.5 & -6.6 & -12.4 & $11.6-$ & -10.1 & $5.2-$ \\
\hline 30 & -16.1 & -11.5 & -22.4 & $20.1-$ & $14.3-$ & 9.1 - \\
\hline 40 & -28.4 & -21.2 & -30.4 & -27.1 & $27.8-$ & $19.1-$ \\
\hline 50 & -37.2 & -26.4 & -34.1 & $31.2-$ & $38.1-$ & $24.7-$ \\
\hline 60 & -44.5 & -36.8 & -36.3 & $35.6-$ & $46.8-$ & $37.1-$ \\
\hline 70 & -50.4 & -45.9 & -39.9 & $37.5-$ & $53.7-$ & $48.3-$ \\
\hline
\end{tabular}

*(-) Shows the decrease in values 


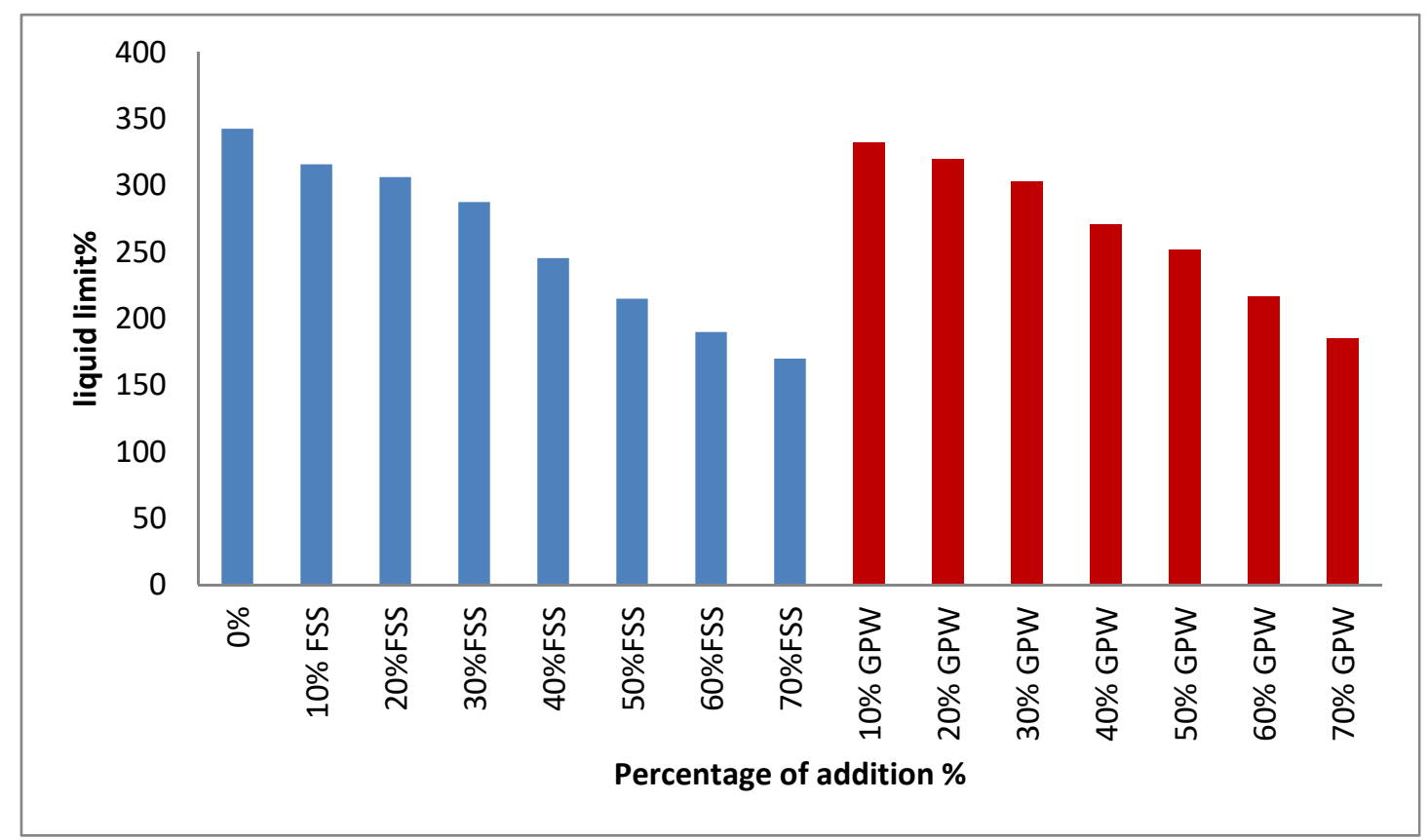

Figure 1. Effects of Fine Silica Sand and Granite Waste Powder Addition on the Liquid Limit

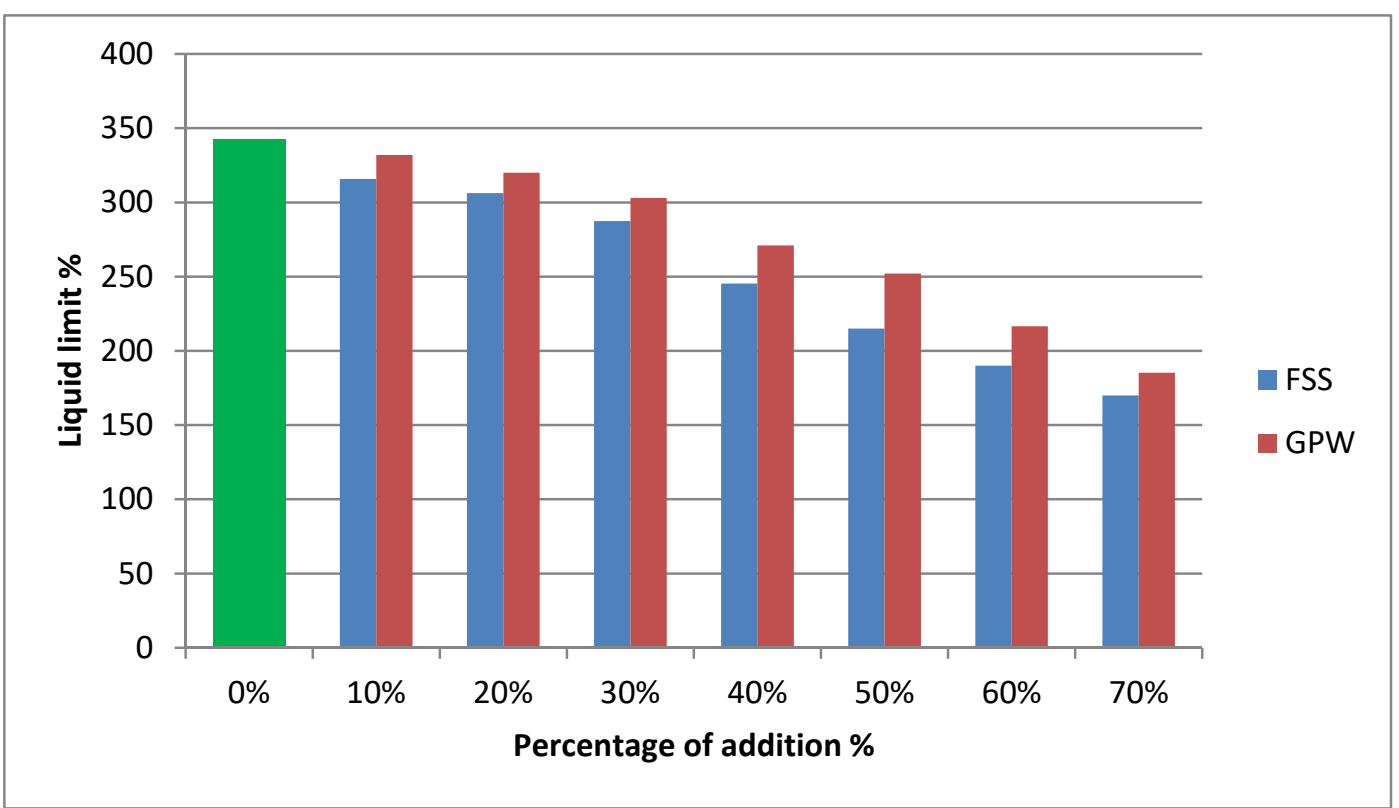

Figure 2. Effects of Fine Silica Sand versus Effects of Granite Waste Powder on the Liquid Limit 


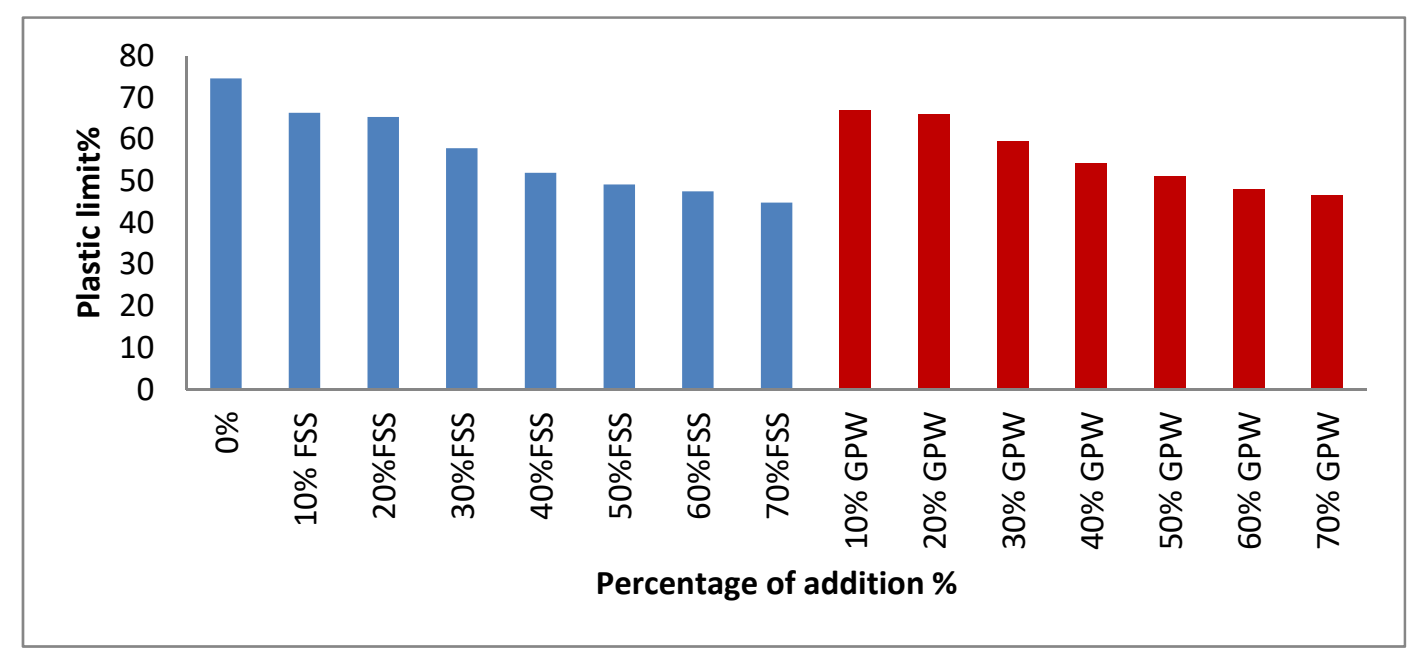

Figure 3. Effects of Fine Silica Sand and Granite Waste Powder Addition on the Plastic Limit

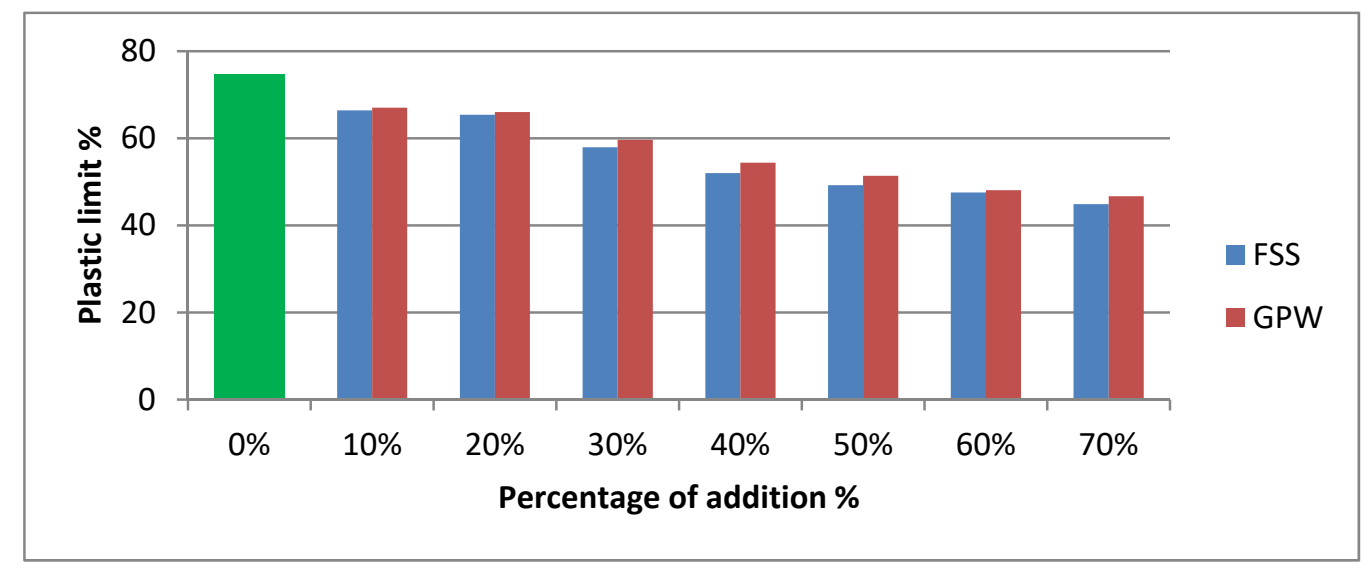

Figure 4. Effects of Fine Silica Sand versus Effects of Granite Waste Powder on the Plastic Limit

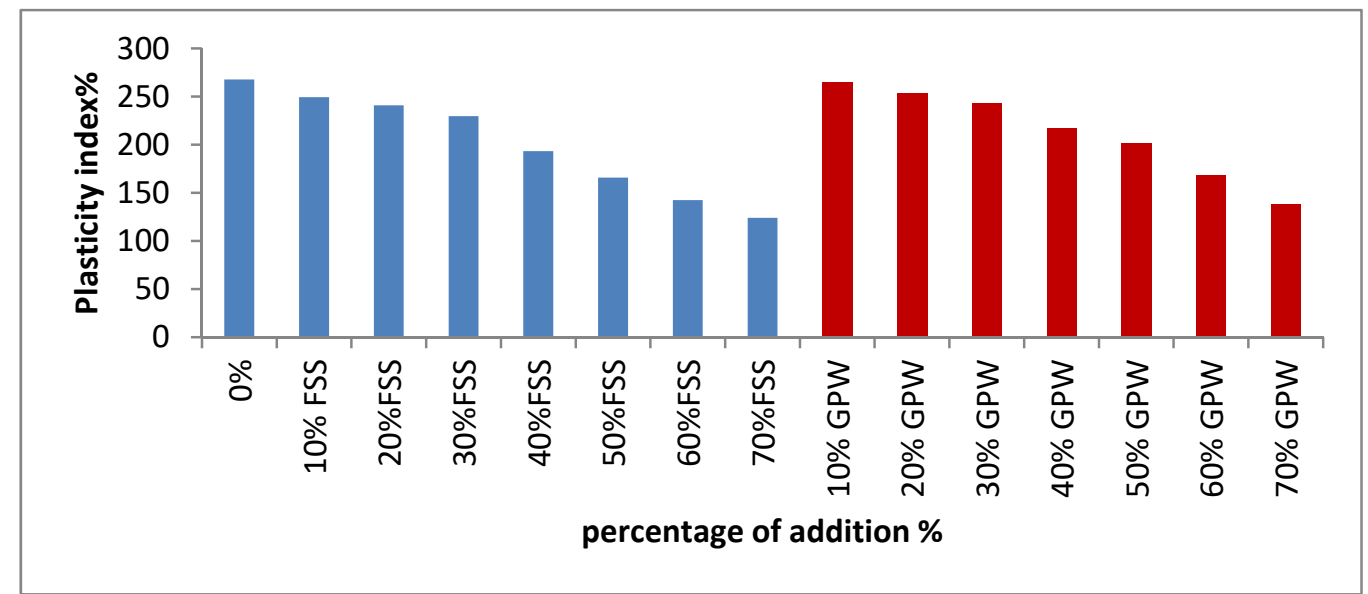

Figure 5. Effects of Fine Silica Sand and Granite Waste Powder Addition on the Plasticity Index 


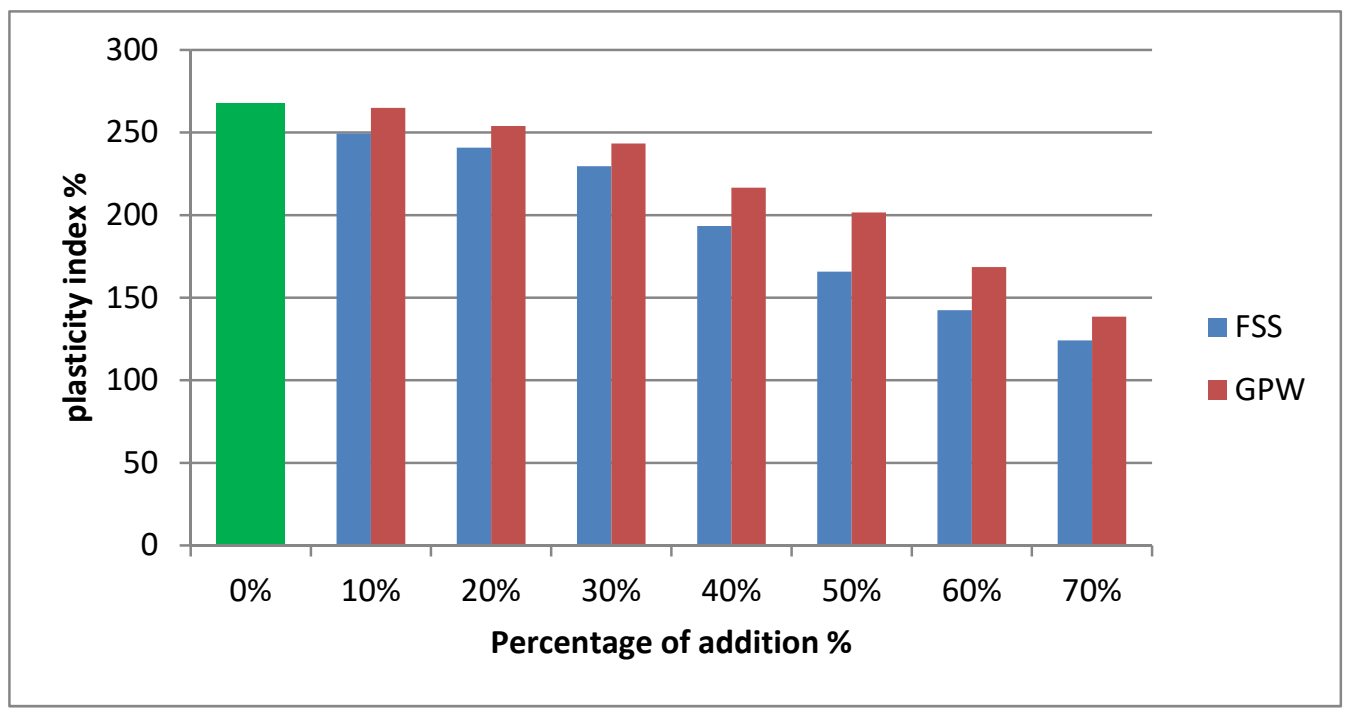

Figure 6. Effects of Fine Silica Sand versus Effects of Granite Waste Powder on the Plasticity Index

Figure1 to Figure 3 shows the relationship between (LL, PL, and PI) and the percentage of fine silica sand and granite powder waste. The relationship between PI and percentage of mixed fine silica sand and the relationship between PI and granite powder waste is also approximately linear. Addition of $70 \%$ fine silica sand reduced the expansive soil plasticity to about $54 \%$ of the initial value. While addition of $70 \%$ granite powder waste reduced the expansive soil plasticity to about $48 \%$.

Addition of fine silica sand from $(0 \%$ to $70 \%)$ decreased the plasticity index value from $267.83 \%$ to $124.12 \%$, while addition of granite powder waste from $(0 \%$ to $70 \%)$ decreased the plasticity index value from $267.83 \%$ to $138.51 \%$ as show in table 3 .

\section{B. Effect of Fine Silica Sand and Granite Powder Waste Addition on Expansive Soils Free Swelling Properties}

Free swell index is the increase in volume of a soil, without any external constraints, on submergence in water. The free swell index may be considered as a property of expansive soil. It reflects the potential of the soil for its expansion. It is determined by finding out the volume of the swollen soil after allowing a specified volume of the dry soil to get soaked in water. The free swell index is expressed as percentage free swell given by the equation below:

$$
\text { Free Swell }=\frac{\text { Final Volume-Initial Volume }}{\text { Initial Volume }} \times 100
$$

Ranjan, G., and Rao, A. S. R. [11] gave the following classification of degree of expansion based on the Free swell index values (Table 4).

Table 4. Degree of expansion and differential free swell index (Ranjan, G., and Rao, A. S. R.) [11]

\begin{tabular}{ll}
\hline Free Swell Index \% & Degree of Expansion \\
\hline Less Than 20 & Low \\
\hline $\mathbf{2 0}$ to35 & Moderate \\
$\mathbf{3 5}$ to50 & High \\
Greater than $\mathbf{5 0}$ & Very High
\end{tabular}

Table 5 and Figure 7 to Figure 10 show the effect of each fine silica sand and granite powder waste stabilizers on free swell index. The free swell decreases with increases of fine silica sand and granite powder waste additives.

Adding $70 \%$ fine silica sand reduced the swell index to $5.66 \%$ from $31.6 \%$ on the first day, and adding $70 \%$ granite powder waste reduced the swelling potential to $6.5 \%$ on the first day.

To explain the effect of fine silica sand and granite powder waste on the swelling potential we can look at the results of $70 \%$ granite powder waste and $70 \%$ fine silica sand after 7 days. $70 \%$ fine silica sand showed a swelling index percentage of $6.6 \%$ and $70 \%$ granite powder waste showed a swelling index percentage of $11 \%$. This shows that fine silica sand is more table4 show that addition of the silica sand and granite powder waste 
change the swelling potential of expansive soils sample which classified as a high swelling potentially soil to low expansive soils.

Table 5. Proposed Expansive Soils Free Swell index and Degree of Expansion

\begin{tabular}{|c|c|c|c|c|c|c|c|c|c|}
\hline \multirow{2}{*}{$\begin{array}{l}\text { Percentage } \\
\text { of Fine } \\
\text { Silica } \\
\text { Sand } \\
\text { Addition }\end{array}$} & \multicolumn{3}{|c|}{$\begin{array}{c}\text { Free Swell Index } \\
(\%)\end{array}$} & \multirow{2}{*}{$\begin{array}{c}\text { Degree of } \\
\text { Expansion } \\
\text { According To } \\
\text { (Ranjan, G., } \\
\text { and Rao, A. S. } \\
\text { R.) [7] }\end{array}$} & \multirow{2}{*}{$\begin{array}{l}\text { Percentage } \\
\text { of Granite } \\
\text { Powder } \\
\text { Waste } \\
\text { Addition }\end{array}$} & \multicolumn{3}{|c|}{$\begin{array}{c}\text { Free Swell Index } \\
(\%)\end{array}$} & \multirow{2}{*}{$\begin{array}{c}\text { Degree of } \\
\text { Expansion } \\
\text { According To } \\
\text { (Ranjan, G., } \\
\text { and Rao, A. S. } \\
\text { R.) [7] }\end{array}$} \\
\hline & $\begin{array}{l}1 \text { days } \\
\text { curing }\end{array}$ & $\begin{array}{l}2 \text { days } \\
\text { curing }\end{array}$ & $\begin{array}{l}7 \text { days } \\
\text { curing }\end{array}$ & & & $\begin{array}{l}1 \text { days } \\
\text { curing }\end{array}$ & $\begin{array}{l}2 \text { days } \\
\text { curing }\end{array}$ & $\begin{array}{l}7 \text { days } \\
\text { curing }\end{array}$ & \\
\hline $\mathbf{0}$ & 31.6 & 43.3 & 58.3 & Very High & 0 & 31.6 & 43.3 & 58.3 & Very High \\
\hline 10 & 28.2 & 36.3 & 50 & High & 10 & 30.33 & 36.66 & 56.3 & Very High \\
\hline 20 & 25.4 & 33.2 & 41.6 & High & 20 & 28.1 & 34.4 & 46.66 & High \\
\hline 30 & 23.8 & 29.5 & 36.8 & Moderate & 30 & 26.6 & 30.1 & 42.33 & Moderate \\
\hline 40 & 19.5 & 27.6 & 31.6 & Moderate & 40 & 21 & 26.5 & 40 & Moderate \\
\hline 50 & 13.3 & 21.6 & 26.5 & Moderate & 50 & 15.5 & 23.6 & 37.66 & Moderate \\
\hline 60 & 9 & 11 & 16.6 & Low & 60 & 10.3 & 14 & 23.3 & Low \\
\hline 70 & 5.66 & 6.0 & 6.6 & Low & 70 & 6.5 & 8.33 & 11 & Low \\
\hline
\end{tabular}

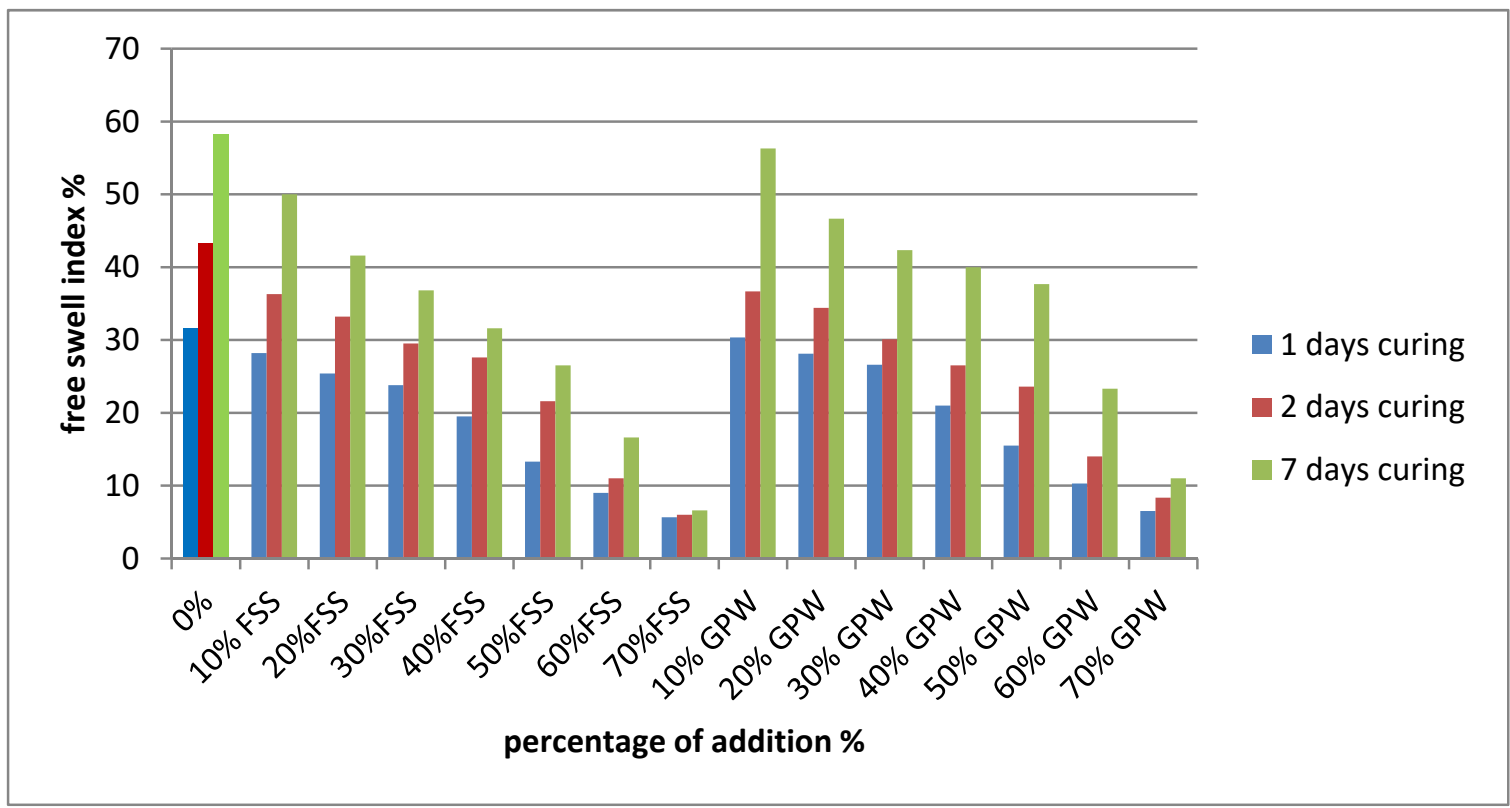

Figure 7. Effects of Fine Silica Sand and Granite Waste Powder on Free Swell Index at Different Curing Age 




Figure 8. Effects of Fine Silica Sand versus Effects of Granite Waste Powder on Free Swell Index at 1days

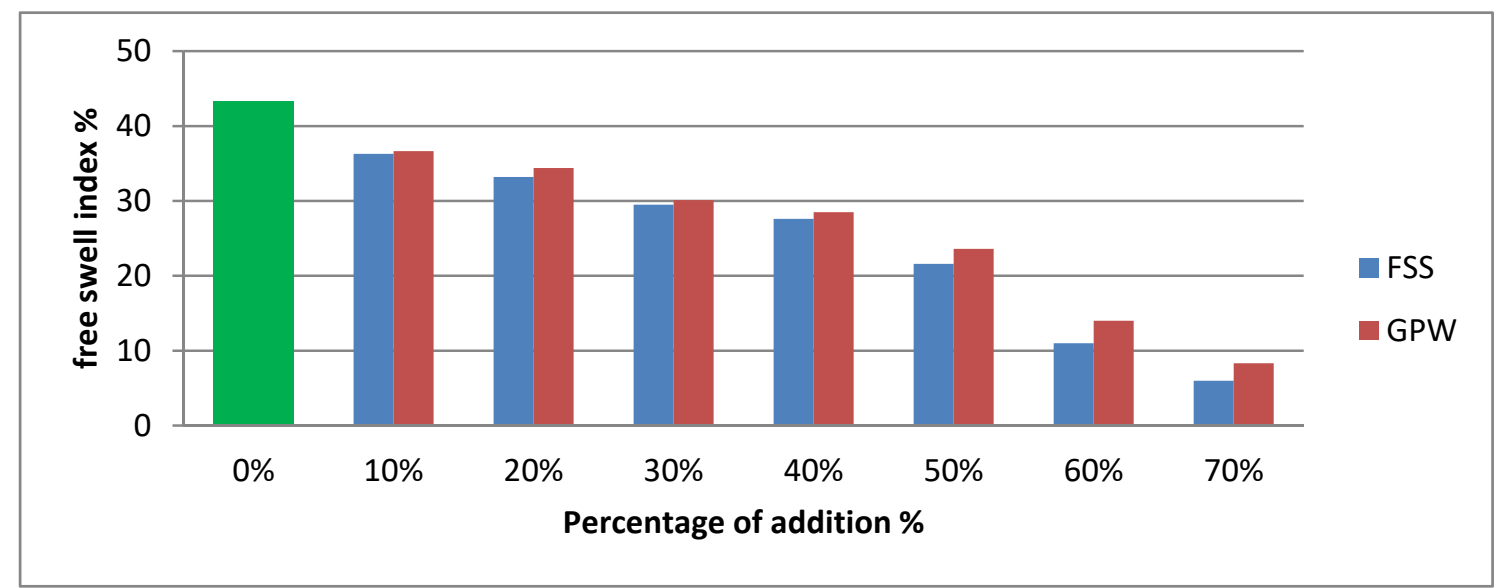

Figure 9. Effects of Fine Silica Sand versus Effects of Granite Waste Powder on Free Swell Index at 2days

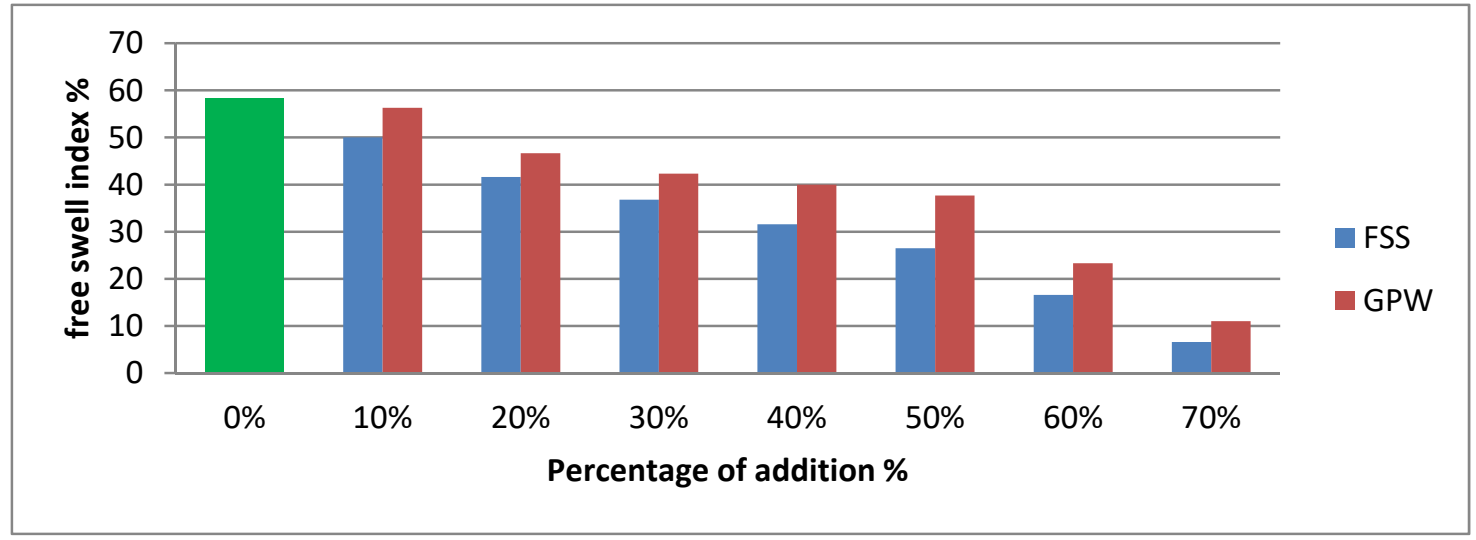

Figure 10. Effects of Fine Silica Sand versus Effects of Granite Waste Powder on Free Swell Index at 7days 4. Effects of Fine Silica Sand and Granite Powder Waste Addition on Rate of Swell of the Expansive Soil

Adding fine silica sand and granite powder waste definitely affects the rate of swell. In comparison between fine silica sand and granite powder waste, fine silica sand is very effective in reducing the rate of swell with time. Especially when $70 \%$ fine silica sand is added to the expansive soil it is conceivable to visualize the decrease in rate of swell as show in table 5 and figure 7 to figure 10.

\section{Comparison of Test Results and Conclusion}

In this study, the suitability of fine silica sand and granite powder waste as stabilizers for swelling potential of an expansive soil was investigated. The effect of fine silica sand and granite powder waste on the index properties and swelling behaviour of expansive soils by means of various laboratory tests such Atterberg limits (liquid limit, plastic limit and plasticity index) and free swelling index test. Fine silica sand and granite powder waste were 
used as additive materials with $10 \%, 20 \%, 30 \%, 40 \%, 50 \%, 60 \& 70 \%$ by dry weight of the expansive soils.

Based on the analysis of laboratory results obtained and comparisons made in the present study, the following conclusions were drawn:

- $\quad$ Liquid limit, plastic limit and plasticity index values of expansive soil decreased with the addition of silica sand and granite powder waste

- Addition of the fine silica sand and granite powder waste change the swelling potential of expansive soils sample which classified as a high swelling potentially soil to low expansive soils.

- Addition of fine silica sand and granite powder waste to the expansive soils sample reduces swell index percentage significantly addition of $70 \%$ fine silica sand change swell index percentages from $58.3 \%$ to $6.6 \%$ after 7 days of curing with reduction percentage of $88.7 \%$, while addition of $70 \%$ granite powder waste change swell index percentages from $58.3 \%$ to $11 \%$ after 7 days of curing with reduction percentage of $81.1 \%$.

- Swelling percentage and rate of swell decrease by increase of curing time for both fine silica sand and granite powder waste soils samples.

- $\quad$ It should be noted that the current laboratory investigation focuses mainly on bentonite materials as soils sample with high expansive potential so it is suggested to use natural expansive soils samples with different degree of swell potential which proves the influence of fine silica sand and granite powder waste on swelling behaviour more exactly.

- $\quad$ On the basis of this study both fine silica sand and granite powder waste can be used as effective additives materials for improvement of expansive soils for the construction of different structures. The utilized of fine silica sand and granite powder waste as additive materials can be economically in regions near to the areas where these materials are obtained.

The results obtained in this study, fine silica sand and granite powder waste have significant change the expansive soils index properties. Therefore, fine silica sand and granite powder waste can be used as stabilizer materials for highly plastic expansive soils. Although the two materials give different results, however, the results obtained using granite powder waste as soil stabilizer were close to fine silica sand results as shown in figure 2 , figure 4 , figure 6 , figure 8 , figure 10 , and table 6 which makes granite powder waste and natural stone powder waste as general can effectively improve the poor properties of expansive soil more over these materials are cost effectively, locally available and environmentally friendly.

Table 6. Percent Changes in Free swell index and Rate of Swell

\begin{tabular}{|c|c|c|c|c|c|c|c|}
\hline \multirow[t]{2}{*}{$\begin{array}{c}\text { Percentage of } \\
\text { Fine Silica Sand } \\
\text { Addition }\end{array}$} & \multicolumn{3}{|c|}{$\begin{array}{c}\% \text { Change in Free Swell } \\
\text { Index } \\
(\%)\end{array}$} & \multirow{2}{*}{$\begin{array}{l}\text { Percentage of } \\
\text { Granite } \\
\text { Powder Waste } \\
\text { Addition }\end{array}$} & \multicolumn{3}{|c|}{$\begin{array}{c}\% \text { Change in Free Swell } \\
\text { Index } \\
(\%)\end{array}$} \\
\hline & $\begin{array}{l}1 \text { days } \\
\text { curing }\end{array}$ & $\begin{array}{l}2 \text { days } \\
\text { curing }\end{array}$ & $\begin{array}{l}7 \text { days } \\
\text { curing }\end{array}$ & & $\begin{array}{l}1 \text { days } \\
\text { curing }\end{array}$ & $\begin{array}{l}2 \text { days } \\
\text { curing }\end{array}$ & $\begin{array}{l}7 \text { days } \\
\text { curing }\end{array}$ \\
\hline $\mathbf{0}$ & 0 & 0 & 0 & 0 & 0 & 0 & 0 \\
\hline 10 & -10.8 & 16.16- & -14.2 & 10 & $4.0-$ & 15.33- & $3.4-$ \\
\hline 20 & 19.6- & $23.3-$ & 28.6- & 20 & $11.1-$ & $20.6-$ & 19.9- \\
\hline 30 & -24.7 & 31.9- & $36.9-$ & 30 & $15.8-$ & $30.5-$ & $27.4-$ \\
\hline 40 & $38.3-$ & $36.3-$ & $45.8-$ & 40 & $33.5-$ & $38.8-$ & $31.4-$ \\
\hline 50 & -57.9 & $50.1-$ & $54.5-$ & 50 & $50.9-$ & $45.5-$ & $35.4-$ \\
\hline 60 & $71.5-$ & $74.6-$ & 71.5- & 60 & $67.4-$ & $67.7-$ & $60.0-$ \\
\hline 70 & $82.1-$ & $86.0-$ & $88.7-$ & 70 & 79.4- & $80.8-$ & 81.1- \\
\hline
\end{tabular}

*(-) Shows the decrease in values

\section{Acknowledgement}

The authors are thankful to Jerash University (Jerash- Jordan) for providing their Laboratories and premises. Our thanks extend to the reviewers for their valuable suggestions that led to enhancement of the quality of article. 


\section{References}

Ene, E., \& Okagbue, C. (2009). Some basic geotechnical properties of expansive soil modified using pyroclastic dust. Engineering Geology, 107(1-2), 61-65. https://doi.org/10.1016/j.enggeo.2009.03.007

Gupta Chayan, \& Sharma Ravi Kumar. (2014). Influence of Marble Dust, Fly Ash and Beas Sand on Sub-Grade Characteristics of Expansive Soil. Journal of Mechanical \& Civil Engineering, 13-18.

Jain, A., Gupta, R., \& Chaudhary, S. (2019). Performance of self-compacting concrete comprising granite cutting waste as fine aggregate. Construction and Building Materials, 221, 539-552. https://doi.org/10.1016/j.conbuildmat.2019.06.104

Mishra, B., \& Mishra, R. S. (2015). Improvement in Characteristics of Expansive Soil by Using Quarry Waste and Its Comparison with Other Materials like Cement and Lime Being Used for Soil Improvement. International Journal of Innovative Research in Science, Engineering and Technology, 4, 7416-7431.

Monica Malhotra, \& Sanjeev Naval. (2013). Stabilization of Expansive Soils Using Low Cost materials. International Journal of Engineering and Innovative Technology, 2(11).

Muntohar, A. S., \& Hantoro, G. (2000). Influence of Rice Husk Ash and Lime on Engineering Properties of a Clayey Subgrade. Electronic Journal of Geotechnical Engineering, 5, 1-13.

O'neıll, M. W., \& Poormoayed, N. (1980). Methodology for Foundations on Expansive Clays. Journal of the Geotechnical Engineering Division, American Society of Civil Engineers, 106(GT12), 1345-1367.

Öncü, Ş., \& Bilsel, H. (2018). Utilization of waste marble to enhance volume change and strength characteristics of sand-stabilized expansive soil. Environmental Earth Sciences, $77(12)$. https://doi.org/10.1007/s12665-018-7638-5

Oriola, F. O. P., \& Moses, G. (2011). Compacted Black Cotton Soil Treated with Cement Kiln Dust as Hydraulic Barrier Material. American Journal of Scientific and Industrial Research, 2, 521-530. https://doi.org/10.5251/ajsir.2011.2.4.521.530

Ramakrishna, A. N., \& Pradeep Kumar, A. V. (2006). Stabilisation of Black Cotton Soil Using Rice Husk Ash and Cement. National Conference on Civil Engineering Meeting the Challenges of Tomorrow, GND Engineering College, Ludhiana, 215-220.

Ranjan G., \& Rao, A. S. R. (2000). Basic and Applied Soil Mechanics. New Age International Publishers. Second Edition.

Selvakumar, S., \& Soundara, B. (2020). Swelling behavior of expansive soils stabilized with expanded polystyrene geofoam inclusion. New Materials in Civil Engineering, 745-776. https://doi.org/10.1016/B978-0-12-818961-0.00024-7

Sumit S., Vishvendra S., \& B. Achary. (2018). Review on effect of marble dust on geotechnical properties of expansive soil. International Journal of Advance Research in Science and Engineering (IJARSE), 7(2).

Talal Masoud, Manal O. Suliman, Shehdeh Ghannam, \& Hesham Alsharie. (2019). Effect of Alkhmhah on Swelling Index Properties of Expansive Soils From Jerash in Jordan. International Review of Basic and Applied Sciences, 7(12), 93-98.

\section{Copyrights}

Copyright for this article is retained by the author(s), with first publication rights granted to the journal.

This is an open-access article distributed under the terms and conditions of the Creative Commons Attribution license (http://creativecommons.org/licenses/by/4.0/). 